\title{
PERTUMBUHAN INDUSTRI ASURANSI JIWA DI INDONESIA: SUATU KAJIAN DARI SISI PENAWARAN
}

\author{
Firdaus Djaelani \\ Program Studi Kebijakkan Sekolah Pascasarjana Universitas Gadjah mada \\ E-mail: djaelani@lps.go.id \\ Jeremias T. Keban \\ Fakultas Ilmu Sosial dan Politik Universitas Gadjah Mada
}

Suad Husnan

Fakultas Ekonomi dan Bisnis Universitas Gadjah Mada

Mamduh M. Hanafi

Fakultas Ekonomi dan Bisnis Universitas Gadjah Mada

\begin{abstract}
Life insurance has become the need in today modern community's life. In Indonesia, the demand on life insurance grew continuously in line with the increase of people's income and awareness on the importance of risk anticipation. To fulfill this demand, the number of life insurance companies always increased as well as various products supplied in the market. However, the contribution of insurance industry, especially life insurance, on Indonesia's economy was relatively low. This research is aimed to analyze factors affecting the life insurance industry growth from supply side. The secondary data was collected from 15 biggest life insurance companies in Indonesia. Meanwhile, the main tools of analysis used were including descriptive statistic and dynamic panel regression. The analysis result shows that the product variety has no impact on the gross premium of life insurance growth, number of policies, and insurance funds. On the reverse, supporting infrastructures and government policy have significant and positive impacts.
\end{abstract}

Keywords: life insurance industry, supply side.

\begin{abstract}
ABSTRAK
Asuransi jiwa telah menjadi kebutuhan dalam kehidupan masyarakat moderen saat ini. Di Indonesia, permintaan asuransi jiwa terus bertumbuh sejalan dengan peningkatan pendapatan dan kepedulian masyarakat terhadap pentingnya antisipasi risiko. Untuk memenuhi permintaan ini, jumlah perusahaan asuransi jiwa senantiasa meningkat dan demikian pula dengan beragam produknya yang yang ditawarkan di pasar. Namun demikian, kontribusi industri asuransi, khususnya asuransi jiwa, terhadap perekonomian Indonesia masih relatif rendah. Penelitian ini bertujuan untuk menganalisis faktor-faktor yang mempengaruhi pertumbuhan industri asuransi jiwa dari sisi penawaran. Data
\end{abstract}




\section{PENGANTAR}

Sektor keuangan merupakan motor penggerak perekonomian di suatu negara. Hal ini disebabkan peran sektor keuangan sebagai penyalur dari pihak yang kelebihan kepada pihak yang kekurangan dana, sehingga berdampak pada kinerja perekonomian (Mishkin, 2004: 7). Apabila sektor keuangan berfungsi dengan baik, maka dana menganggur pada pihak yang kelebihan dana dapat dikurangi, sedangkan kebutuhan investasi atau konsumsi dari pihak yang kekurangan dana dapat dipenuhi.

Sistem keuangan sangat kompleks, karena mencakup interaksi pasar keuangan, lembaga keuangan, dan produk keuangan (Warjiyo, 2007: 12). Berbagai studi menunjukkan bahwa aliran dana secara tidak langsung melalui lembaga keuangan tidak kalah pentingnya dalam perekonomian dibandingkan aliran dana langsung melalui pasar keuangan (Mishkin, 2004: 171). Bank, perusahaan asuransi, dana pensiun, dan reksadana telah berperan dalam perdagangan instrumen keuangan.

Penguatan lembaga keuangan non bank di Indonesia diperlukan untuk mendukung tercapainya sasaran pembangunan jangka panjang melalui penempatan obligasi di pasar domestik, pembiayaan infrastruktur, dan perluasan lapangan kerja dengan penyediaan sumber dana murah bagi usaha kecil dan menengah (Bank Dunia, 2006: 1-2). Salah satu industri lembaga keuangan non bank yang berperan penting dalam sistem keuangan Indonesia adalah asuransi. Industri ini memiliki pangsa pasar kedua terbesar setelah perbankan dan merupakan pemegang pangsa pasar terbesar dalam industri lembaga keuangan non bank (Bank Indonesia, 2010: 23).

Namun, kontribusi industri asuransi pada perekonomian Indonesia masih tergolong rendah. Kontribusi premi bruto industri asuransi hingga tahun 2009 masih di bawah 2 persen dari Produk Domestik
Bruto (PDB). Padahal, di negara-negara tetangga, kontribusi premi bruto industri asuransi sudah lebih dari 19 persen terhadap PDB. Misalnya di Malaysia 19,5 persen dan Singapura 49,8 persen dari PDB (Bank Dunia, 2005). Masih rendahnya kontribusi industri asuransi terhadap perekonomian di Indonesia dapat disebabkan oleh beberapa faktor.

Rendahnya kontribusi industri asuransi terhadap perekonomian berimplikasi bahwa prospek industri ini masih sangat besar. Premi bruto terus meningkat dengan pertumbuhan rata-rata di atas 20 persen per tahun. Hal ini memperkuat keyakinan bahwa industri asuransi di Indonesia masih sangat potensial untuk dikembangkan melalui sinergi di antara para pelaku pasar dan pemerintah sebagai regulator.

Industri asuransi jiwa memiliki ratarata pertumbuhan premi bruto tertinggi selama tahun 2005-2009, yaitu 29,96 persen, selain menjadi kontributor terbesar $(57,99$ persen pada tahun 2009). Pertumbuhan industri asuransi jiwa diikuti oleh asuransi Pegawai Negeri Sipil (PNS) dan Tentara Nasional Indonesia (TNI)/Kepolisian Republik Indonesia (POLRI) dengan ratarata pertumbuhan premi bruto 23,27 persen. Selanjutnya asuransi sosial dan Jamsostek dengan rata-rata pertumbuhan premi bruto 21,66 persen, serta asuransi kerugian dan reasuransi dengan rata-rata pertumbuhan premi bruto 15,58 persen.

Dalam penelitian ini akan diuji faktorfaktor yang mempengaruhi pertumbuhan industri asuransi jiwa di Indonesia ditinjau dari sisi manajemen perusahaan asuransi jiwa. Penelitian menggunakan data pada tingkat perusahaan asuransi jiwa. Terdapat dua aspek yang dianalisis, yaitu faktor-faktor 
yang diduga mempengaruhi dan peran kebijakan pemerintah terhadap pertumbuhan industri asuransi jiwa di Indonesia.

Penelitian ini merupakan penelitian eksplanatoris yang berupaya menganalisis faktor-faktor yang mempengaruhi pertumbuhan industri asuransi jiwa di Indonesia dari sisi penawaran. Beberapa penelitian terdahulu telah membahas tentang pertumbuhan industri asuransi jiwa dari sisi permintaan dan faktor-faktor yang mempengaruhinya, sedangkan penelitian yang membahas dari sisi penawaran belum ditemukan. Penelitian-penelitian tersebut sangat beragam, mulai dari data yang digunakan hingga maupun lingkup geografis.

Berdasarkan data yang digunakan, penelitian tentang pertumbuhan permintaan industri asuransi jiwa dapat dibagi menjadi dua kategori, yaitu penelitian dengan pendekatan agregat dan disagregat (Eduard, 2004). Penelitian melihat permintaan industri asuransi jiwa secara luas, di mana variabel dependen dan independen adalah variabel pada tingkat industri, ekonomi makro, dan demografi. Beberapa penelitian yang menggunakan pendekatan ini antara lain Truett dan Truett (1990), Browne dan Kim (1993), Outreville (1996), Rubayah dan Zaidi (2000), Beck dan Webb (2002), Lim dan Haberman (2004), serta Lenten dan Rulli (2005). Adapun dalam penelitian disagregat, dilakukan analisis dalam lingkup mikro, di mana data yang digunakan diperoleh dari sampel individu pemegang polis asuransi jiwa, seperti yang telah dilakukan oleh Eduard (2004).

Terdapat gap pada penelitian tentang pertumbuhan industri asuransi jiwa, yaitu masih belum pernah dilakukannya penelitian yang menggunakan tinjauan dari sisi penawaran atau dari sudut pandang manajemen perusahaan sebagai penjual produk asuransi jiwa. Selain itu, penelitian yang menggunakan pendekatan disagregat juga masih belum banyak dilakukan. Untuk mengisi gap tersebut, penelitian ini menganalisis pertumbuhan industri asuransi jiwa ditinjau dari sisi penawaran.
Dari sisi manajemen perusahaan asuransi jiwa, keragaman produk merupakan salah satu faktor yang sangat penting dalam mendukung kesuksesan perusahaan untuk menjual produknya. Keragaman produk didefinisikan sebagai himpunan dari berbagai macam produk yang ditawarkan perusahaan untuk dijual kepada konsumen (Kotler dan Keller, 2006:381). Faktor lain yang juga dipandang penting dalam menentukan kesuksesan penjualan polis perusahaan asuransi jiwa adalah sarana dan prasarana penunjang yang meliputi teknologi, pengetahuan dan keahlian agen asuransi, serta alat-alat penunjang pemasaran lainnya, seperti package proposal.

Populasi penelitian ini adalah perusahaan asuransi jiwa di Indonesia. Untuk menarik kesimpulan atas populasi dilakukan pengambilan sampel perusahaan asuransi jiwa mengikuti the law of the vital few atau hukum 80/20 Pareto (Tracy, 2007: 1) yang menyatakan sekitar 80 persen dari dampak berasal dari 20 persen sebab. Dipilih 15 perusahaan asuransi jiwa terbesar berikut ini sebagai sampel yang secara total menguasai 87,70 persen pangsa pasar di Indonesia.

Tabel 1. Daftar Nama Dan Total Aset Sampel Perusahaan Asuransi Jiwa

\begin{tabular}{|c|c|c|c|}
\hline No. & Nama Perusahaan & Kategori & Aset \\
\hline 1. & $\begin{array}{l}\text { Asuransi } \\
\text { Jiwa Bersama } \\
\text { Bumiputera } 1912\end{array}$ & nasional & $11,899,079$ \\
\hline 2. & $\begin{array}{l}\text { PT. AIA Financial } \\
\text { (d/h PT AIG Life) }\end{array}$ & joint venture & $10,472,200$ \\
\hline 3. & $\begin{array}{l}\text { PT. Prudential Life } \\
\text { Assurance }\end{array}$ & joint venture & $10,332,033$ \\
\hline 4. & $\begin{array}{l}\text { PT. Asuransi Jiwa } \\
\text { Manulife Indonesia }\end{array}$ & joint venture & $9,692,866$ \\
\hline 5. & $\begin{array}{l}\text { PT. Asuransi Jiwa } \\
\text { Sinarmas }\end{array}$ & nasional & $6,650,568$ \\
\hline 6. & PT. Panin Life Tbk. & nasional & $5,902,537$ \\
\hline 7. & $\begin{array}{l}\text { PT. Asuransi } \\
\text { Allianz Life } \\
\text { Indonesia }\end{array}$ & joint venture & $5,785,608$ \\
\hline 8. & $\begin{array}{l}\text { PT. Avrist } \\
\text { Assurance (d/h PT } \\
\text { AIA Indonesia) }\end{array}$ & joint venture & $5,450,287$ \\
\hline 9. & $\begin{array}{l}\text { PT. Asuransi } \\
\text { Jiwasraya (Persero) }\end{array}$ & nasional & $4,888,911$ \\
\hline
\end{tabular}




\begin{tabular}{llll}
\hline 10. & $\begin{array}{l}\text { PT. Asuransi Jiwa } \\
\text { Sequis Life }\end{array}$ & nasional & $4,319,181$ \\
\hline 11. & $\begin{array}{l}\text { PT. Asuransi Jiwa } \\
\text { Mega Life }\end{array}$ & nasional & $3,695,709$ \\
\hline 12. & $\begin{array}{l}\text { PT. AXA Mandiri } \\
\text { Financial Services }\end{array}$ & joint venture & $3,573,971$ \\
\hline 13. & $\begin{array}{l}\text { PT. Asuransi Sun } \\
\text { Life Financial } \\
\text { Indonesia }\end{array}$ & joint venture & $2,623,495$ \\
\hline 14. & $\begin{array}{l}\text { PT. Asuransi Jiwa } \\
\text { Central Asia Raya }\end{array}$ & nasional & $2,464,091$ \\
\hline 15. & $\begin{array}{l}\text { PT. Indolife } \\
\text { Pensiontama }\end{array}$ & nasional & $2,059,283$ \\
\hline & Total Pangsa & $87,70 \%$ & $89,809,821$ \\
\hline
\end{tabular}

Data yang digunakan dalam penelitian ini adalah data sekunder yang diperoleh dari laporan tahunan 15 sampel perusahaan asuransi jiwa, buku Indonesian Insurance terbitan Biro Perasuransian, Bapepam-LK, Kementerian Keuangan Republik Indonesia, Federasi Asosiasi Perasuransian Indonesia (FAPI), Dewan Asuransi Indonesia (DAI), website Bank Indonesia (www.bi.go.id), catatan, makalah, dan artikel lain yang berhubungan dengan obyek penelitian.

\section{Hipotesis dan Alat Analisis}

Alat analisis yang digunakan untuk menguji hipotesis dan menarik kesimpulan pada penelitian ini adalah regresi panel dinamis Terdapat 4 hipotesis yang diuji.

Hipotesis 1:

$H_{01}$ : Keragaman produk tidak berpengaruh terhadap pertumbuhan premi bruto, jumlah polis, dan uang pertanggungan perusahaan asuransi jiwa.

$H_{A 1}$ : Keragaman produk berpengaruh positif terhadap pertumbuhan premi bruto, jumlah polis, dan uang pertanggungan perusahaan asuransi jiwa.

Hipotesis 2:

$H_{02}$ : Sarana dan prasarana penunjang tidak berpengaruh terhadap pertumbuhan premi bruto, jumlah polis, dan uang pertanggungan perusahaan asuransi jiwa.

$H_{A 2}$ : Sarana dan prasarana penunjang berpengaruh positif terhadap pertumbuhan premi bruto, jumlah polis, dan uang pertanggungan perusahaan asuransi jiwa.
Hipotesis 3:

$H_{010}$ : Kepemilikan asing tidak berpengaruh terhadap pertumbuhan premi bruto, jumlah polis, dan uang pertanggungan perusahaan asuransi jiwa.

$H_{A 10}$ : Kepemilikan asing berpengaruh positif terhadap pertumbuhan premi bruto, jumlah polis, dan uang pertanggungan perusahaan asuransi jiwa.

Hipotesis 4:

$H_{011}$ : Kebijakan pemerintah tidak berpengaruh terhadap pertumbuhan premi bruto, jumlah polis, dan uang pertanggungan perusahaan asuransi jiwa.

$H_{A 11}$ : Kebijakan pemerintah berpengaruh positif terhadap pertumbuhan premi bruto, jumlah polis, dan uang pertanggungan perusahaan asuransi jiwa.

Model pooled regression untuk menguji ke-4 hipotesis adalah berikut ini.

$\mathrm{Y}_{\mathrm{it}}=\mathrm{b}_{0}+\mathrm{b}_{1} \mathrm{PL}_{\mathrm{it}}+\mathrm{b}_{2} \mathrm{RCAP}_{\mathrm{it}}+\mathrm{b}_{3} \mathrm{GSDM}_{\mathrm{it}}+\mathrm{b}_{4} \mathrm{GRND}_{\mathrm{it}}$ $+b_{5}$ GARE $_{\text {it }}+\mathrm{b}_{6}$ GAGN $_{\text {it }}+\mathrm{b}_{7}$ PAKDES $_{t}+$ $\mathrm{b}_{8} \mathrm{UU}_{\mathrm{t}}+\mathrm{b}_{9} \mathrm{KMK}_{\mathrm{t}}+\mathrm{b}_{10} \mathrm{ASA}_{\mathrm{t}}+\mathrm{b}_{11}$ DKRISIS $_{\mathrm{t}}+$ $b_{12} D J V_{i}+e_{i t}$

di mana:

$Y_{\text {it }} \quad=$ pertumbuhan premi bruto (GPB), jumlah polis (GJP), dan uang pertanggungan (GUP) perusahaan;

$P L_{i t} \quad=$ jumlah product line yang ditawarkan perusahaan;

$R C A P_{i t}=$ rasio capital expenditure terhadap aset perusahaan;

$\mathrm{GSDM}_{i t}=$ pertumbuhan biaya SDM perusahaan;

$G R N D_{i t}=$ pertumbuhan biaya research and development perusahaan;

GARE $_{i t}=$ pertumbuhan agent-related expense perusahaan;

$G A G N_{i t}=$ pertumbuhan jumlah agen perusahaan;

PAKDES $_{t}=$ Paket Desember (Pakdes) 1988;

UU $_{t}=$ UU No. 2 Tahun 1992, KMK No. 221-226 Tahun 1993, dan PP No. 73 Tahun 1993;

KMK $_{t}=$ KMK No. 481 Tahun 1999 dan PP No. 63 tahun 1999;

$A S A_{t}=$ KMK No. 421-426 Tahun 2003; 


$$
\begin{array}{rlr}
\text { DKRISIS }_{t}= & \text { variabel dummy krisis pada } \\
& \text { waktut; } \\
\text { DJV } V_{i}= & \text { variabel dummy struktur } \\
& \text { kepemilikan joint venture } \\
& \text { perusahaan; dan } \\
= & \text { residual error persamaan regresi } \\
& \text { panel. }
\end{array}
$$

\section{PEMBAHASAN}

\section{Statistik Deskriptif}

Rata-rata pertumbuhan premi bruto (GPB?) ke-15 perusahaan asuransijiwa adalah 53,03 persen pertahun, dengan median 27,52 persen pertahun, dan standar deviasi 136,89 persen. Pertumbuhan premi bruto tertinggi mencapai 185,45 persen dan terendah $-69,66$ persen. Selanjutnya, rata-rata pertumbuhan jumlah polis asuransi jiwa (GJP?) sebesar 22,71 persen pertahun, median 12,53 persen pertahun, dan standar deviasi 67,82 persen. Pertumbuhan jumlah polis tertinggi adalah 987,14 persen dan terendah -34,62 persen. Adapun rata-rata pertumbuhan uang pertanggungan (GUP?) adalah 31,05 persen pertahun dengan median 21,40 persen pertahun dan standar deviasi 46,26 persen. Pertumbuhan jumlah uang pertanggungan tertinggi adalah 325,93 persen, sedangkan terendah sebesar $-41,05$ persen. Berarti kisaran pertumbuhan uang pertanggungan lebih sempit jika dibandingkan dengan jumlah polis asuransi jiwa.

Jumlah product line yang ditawarkan (PL?) memiliki rata-rata 5,18 lini pertahun, median 6 lini per tahun, dan standar deviasi 1,31 lini. Rasio capital expenditure terhadap aset perusahaan asuransi jiwa (RCAP?) memiliki rata-rata 0,70 persen, median 0,29 persen, dan standar deviasi 1,02 persen. Rata-rata pertumbuhan biaya SDM (GSDM?) adalah 37,38 persen pertahun, dengan median 19,46 persen pertahun dan standar deviasi 188,67 persen. Selanjutnya, pertumbuhan biaya research and development (GRND?) memiliki rata-rata 30,04 persen pertahun, median 18,27 persen pertahun, dan standar deviasi 73,06 persen. Pertumbuhan agent-related expense atau biaya keagenan (GARE?) memiliki ratarata 42,84 persen per tahun, median 22,46 persen pertahun, dan standar deviasi 107,46 persen. Sedangkan rata-rata pertumbuhan jumlah agen (GAGN?) adalah 20,28 persen pertahun, dengan median 12,34 persen pertahun dan standar deviasi 49,74 persen.

\section{Uji Stasioneritas Data Panel}

Regresi panel yang digunakan adalah suatu model dinamis (dynamicpanel regression), sehingga memerlukan uji stasioneritas terhadap setiap variabel yang dianalisis. Uji stasioneritas bertujuan untuk menghindari kemungkinan terjadinya regresi palsu atau spurious regression yang tidak memiliki makna secara ekonomi (Gujarati, 2004). Uji stasioneritas dilakukan dengan menggunakan Levin, Lin and Chu t, $A D F$, dan PPunit root test.

Pada $p$-value dari statistik Levin, Lin and Chu t, W-statistics, ADF, dan PP variabel pertumbuhan premi bruto (GPB) kurang dari 0,01 . Berarti $H_{0}$ bahwa data memiliki unit root atau data tidak stasioner dapat ditolak secara statistik pada tingkat kepercayaan 99 persen. Variabel pertumbuhan premi bruto telah memenuhi asumsi stasioneritas, sehingga dapat digunakan untuk analisis lebih lanjut menggunakan model regresi panel dinamis.

Nilai $p$-value dari statistik Levin, Lin and Chut,W-statistics, ADF, dan PP untuk variabel pertumbuhan jumlah polis (GJP), lebih kecil dari $0,01 . H_{0}$ bahwa data memiliki unit root atau data tidak stasioner secara statistik dapat ditolak pada tingkat 99 persen. Dengan demikian, variabel pertumbuhan jumlah polis telah memenuhi asumsi stasioneritas dan dapat digunakan untuk analisis lebih lanjut dengan model regresi panel dinamis.

Diketahui $p$-value dari statistik Levin, Lin and $C h u t, W$-statistics, ADF, dan PP variabel pertumbuhan jumlah uang pertanggungan (GUP) bernilai kurang dari 0,01. Berarti $H_{0}$ bahwa data memiliki unit root atau data tidak stasioner dapat ditolak secara statistik pada tingkat 99 persen. Variabel pertumbuhan uang pertanggungan telah memenuhi asumsi stasioneritas, sehingga dapat digunakan untuk analisis lebih lanjut dengan model regresi panel dinamis. 
Hasilujimenunjukkan bahwap-value dari statistik Levin, Lin and Chu,$W$-statistics, ADF, dan PP variabel product line yang ditawarkan (PL) lebih kecil dari 0,01. Maknanya adalah $H_{0}$ bahwa data memiliki unit root atau data tidak stasioner secara statistik dapat ditolak pada tingkat kepercayaan 99 persen. Oleh karena itu, variabel product line yang ditawarkan telah memenuhi asumsi stasioneritas untuk analisis lebih lanjut dengan model regresi panel dinamis.

Uji stasioneritas selanjutnya dilakukan terhadap variabel rasio capital expenditure terhadap aset perusahaan asuransi jiwa (RCAP). Ditemukan p-value dari statistik Levin, Lin and Chu t, W-statistics, ADF, dan PP variabel RCAP kurang dari 0,01, sehingga secara statistik $H_{0}$ bahwa data memiliki unit root atau data tidak stasioner dapat ditolak pada tingkat kepercayaan 99 persen. Dengan demikian, variabel rasio capital expenditure terhadap aset perusahaan asuransi jiwa telah memenuhi asumsi stasioneritas dan dapat digunakan untuk analisis lebih lanjut dengan model regresi panel dinamis.

Untuk pertumbuhan biaya SDM (GSDM), p-value dari $W$-statistics, ADF, dan PP lebih kecil dari 0,01 yang menunjukkan $H_{0}$ bahwa data memiliki unit root atau data tidak stasioner dapat ditolak pada tingkat kepercayaan 99 persen. Namun, uji statistik Levin, Lin, and Chu tmenghasilkan $p$-value yang lebih besar dari 0,05, sehingga menghasilkan kesimpulan yang bertentangan, yaitu bahwa data masih mengandung unit root atau tidak stasioner.

Hal ini kemungkinan disebabkan data memiliki tren deterministik. Apabila data yang tidak stasioner dipaksakan untuk digunakan sebagai input model regresi, maka estimasi yang dihasilkan dikatakan lancing atau tidak bermakna. Solusi untuk menyelesaikan persoalan ini adalah dengan uji stasioneritas dengan memasukkan komponen intercept dan trend yang hasilnya disajikan pada Lampiran 8.

Terlihat bahwa p-value dari statistik Levin, Lin and Chu t, W-statistics, ADF, dan PP untuk variabel pertumbuhan biaya SDM
(GSDM) telah kurang dari 0,01. Dengan memasukkan intercept dan trend, terdapat satu uji statistik lagi yang digunakan, yaitu Breitung t-stat yang juga menghasilkan p-value yang kurang dari 0,01. Berdasarkan uji-uji yang telah dilakukan, maka secara statistik dapat diyakini bahwa data telah stasioner pada tingkat kepercayaan 99 persen. Data yang telah stasioner layak digunakan untuk untuk analisis lebih lanjut dengan menggunakan model regresi panel dinamis.

Kegiatan penelitian dan pengembangan memainkan peran yang semakin penting dalam menunjang kinerja perusahaan. Apalagi dengan tingkat persaingan yang terus meningkat seiring dengan dinamika perekonomian dan globalisasi yang didukung penggunaan teknologi informasi dan komunikasi. P-value dari statistik Levin, Lin and Chu $\mathrm{t}, \mathrm{ADF}$, dan PP untuk variabel pertumbuhan biaya research and development lebih kecil dari dari 0,01. Berarti $H_{0}$ bahwa data memiliki unit root atau data tidak stasioner dapat ditolak secara statistik pada tingkat kepercayaan 99 persen. Variabel pertumbuhan biaya research and development telah memenuhi asumsi stasioneritas dan dapat digunakan untuk analisis lebih lanjut dengan model regresi panel dinamis. $p$-value dari statistik Levin, Lin and $\mathrm{Chu} t, \mathrm{ADF}$, dan $\mathrm{PP}$ variabel pertumbuhan biaya agent-related kurang dari 0,01. Fakta ini secara statistik bermakna $H_{0}$ bahwa data memiliki unit root atau data tidak stasioner dapat ditolak pada tingkat kepercayaan 99 persen. Variabel pertumbuhan biaya agent-related telah memenuhi asumsi stasioneritas, sehingga dapat digunakan untuk analisis lebih lanjut dengan model regresi panel dinamis.

Diketahui bahwa p-value dari statistik Levin, Lin and Chu t, ADF, dan PP untuk variabel pertumbuhan jumlah agen lebih kecil dari 0,01. Secara statistik, $H_{0}$ bahwa data memiliki unit root dapat ditolak pada tingkat kepercayaan 99 persen. Dengan demikian, variabel pertumbuhan jumlah agen memenuhi asumsi stasioneritas, sehingga dapat digunakan untuk analisis lebih lanjut. 


\section{Uji Multikolinearitas}

Langkah berikutnya sebelum pemodelan regresi data panel adalah menguji ada tidaknya keterkaitanmultikolinieritas diantaravariabelvariabel independen yang digunakan. Uji dilakukan dengan menggunakan statistik korelasi Pearson dengan batasan nilai korelasi lebih dari atau sama dengan 0,8 . Hasil uji multikolinieritas menunjukkan bahwa nilai korelasi Pearson seluruh variabel independen yang digunakan kurang dari 0,8 . Berarti tidak terjadi pelanggaran terhadap asumsi multikolinieritas yang dapat mengurangi validitas hasil estimasi.

\section{Model Regresi Panel Dinamis Pertumbuhan Premi Bruto}

Pemodelan regresi data panel dilakukan dalam beberapa tahap seperti Gambar 1 . Tahap pertama adalah pembentukan model Pooled Least Square (PLS) yang diikuti oleh uji Chow. Tahap selanjutnya adalah pembentukan Random Effect Model (REM) yang dilengkapi dengan uji Hausmann. Sebagai tahap yang terakhir adalah pembentukan Fixed Effect Model (FE

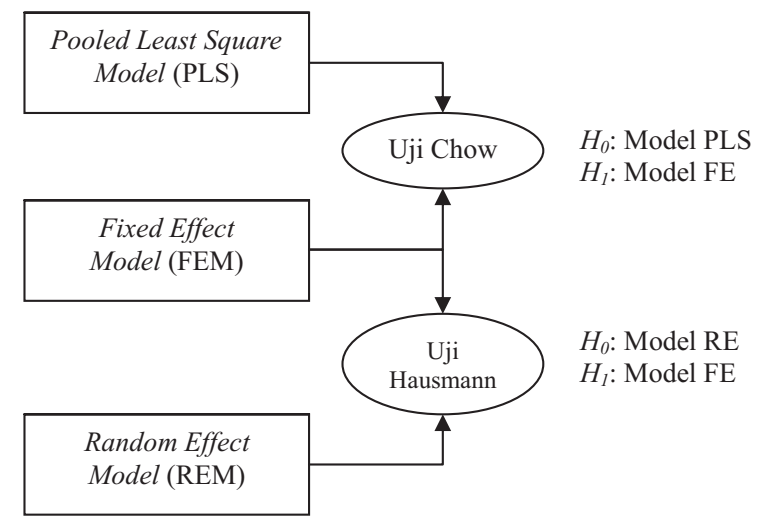

Gambar 1. Tahap Pemodelan Regresi Data Panel Sumber: Diolah dari Sanjoyo (2007).

\section{Uji Chow Pertumbuhan Premi Bruto}

Hasil uji Chow yang membandingkan model regresi panel variabel pertumbuhan premi bruto (GPB) dengan menggunakan model PLS dan FEM Nilai $p$-value untuk Cross Section F dan Cross Section Chi Square berturutturut sebesar 0,1646 dan 0,1189. Kedua nilai ini lebih besar dari 0,05 , sehingga $H_{0}$ bahwa model PLS lebih unggul daripada FEM tidak dapat ditolak secara statistik pada tingkat keyakinan 95 persen. Dengan demikian, model PLS yang lebih direkomendasikan untuk variabel GPB.

\section{Uji Hausman Pertumbuhan Premi Bruto}

Langkah selanjutnya adalah hasil uji Hausman yang membandingkan antara model regresi panel variabel GPB dengan menggunakan FEM dan REM. Hasil uji Hausman menunjukkan nilai $p$-value untuk Cross Section Random sebesar 0,0210 yang lebih kecil dari 0,05. Berarti $H_{0}$ bahwa REM lebih unggul daripada FEM secara statistik dapat ditolak pada tingkat keyakinan 95 persen. Dengan demikian, dapat disimpulkan bahwa FEM yang lebih direkomendasikan untuk variabel GPB.

\section{Model Awal Pertumbuhan Premi Bruto}

Telah diketahui bahwa hasil uji Hausman menunjukkan FEM lebih unggul dari REM, sedangkan hasil uji Chow menunjukkan model PLS lebih unggul daripada FEM. Dengan demikian, model PLS adalah model yang paling optimal untuk memodelkan variabel pertumbuhan premi bruto. Setelah dimasukkan variabel dummy berupa kebijakan Paket Desember (PAKDES), UU Perasuransian, KMK No. 481 Tahun 1999 (KMK), rangkaian KMK No. 421-426 Tahun 2003 (ASA), kondisi krisis (DKRISIS), dan perusahaan asuransi jiwa joint venture (DJV), maka diperoleh hasil estimasi regresi data panel.

\section{Uji Serial Correlation Dan \\ Heteroscedasticity Model Pertumbuhan Premi Bruto}

Setelah diperoleh model awal Pertumbuhan Premi Bruto (GPB) dengan model PLS, maka langkah berikutnya adalah melakukan pengujian asumsi klasik dan penyesuaian model jika ditemukan pelanggaran. Uji asumsi klasik yang dimaksudkan adalah uji korelasi serial dan heteroskedastisitas. 
Adanya pelanggaran terhadap asumsi serial correlation dapat dideteksi dengan melihat nilai statistik Durbin Watson (DW). Aturan umum yang digunakan adalah jika nilai statistik DW mendekati 2, maka dapat diyakini bahwa model telah terbebas dari pelanggaran asumsi serial correlation. Statistik DW untuk persamaan regresi tersebut adalah 1,945 . Dengan angka DW yang mendekati 2 tersebut, dapat disimpulkan bahwa model yang diestimasi tidak mengandung serial correlation.

Pengujian heteroskedastisitas ditempuh dengan menggunakan Lagrange Multiplier (LM). Hasil uji LM untuk model awal diperoleh $p$-value untuk statistik Chi-Square uji LM 0,0000 yang berarti lebih kecil dari 0,01 . Maknanya adalah $H_{0}$ bahwa model bersifat homoskedastik dapat ditolak pada tingkat kepercayaan 99 persen. Dengan kata lain, model regresi data panel yang digunakan mengandung heteroskedastik. Cara mengatasi permasalahan ini adalah dengan melakukan estimasi ulang terhadap model awal. Estimasi disempurnakan dengan menambahkan cross-section weight. Hasil estimasi ulang terhadap model regresi data panel. Terlihat bahwa angka DW mendekati 2, sehingga selain lolos uji asumsi heteroskedastisitas, model regresi data panel juga lolos uji asumsi korelasi serial.

\section{Interpretasi Parameter Model Akhir Regresi Panel Pertumbuhan Premi Bruto}

Berdasarkan hasil estimasi diketahui bahwa terdapat beberapa $p$-value yang lebih kecil dari 0,01, namun sebagian lainnya lebih besar dari 0,05. Koefisien variabel independen yang mempunyai $p$-value lebih kecil dari 0,01 atau signifikan pada tingkat kepercayaan 95 persen adalah pertumbuhan biaya SDM (GSDM), pertumbuhan biaya agent-related (GARE), dan variabel dummy perusahaan joint venture (DJV). Dengan demikian, dapat disimpulkan bahwa ketiga variabel berpengaruh signifikan dan positif terhadap pertumbuhan premi bruto perusahaan asuransi jiwa di Indonesia.
Selain itu, $p$-value dari koefisien variabel independen dummy Paket Desember Tahun 1988 dengan time lag 2 tahun (PAKDES2), UU Perasuransian dengan time lag 2 tahun (UU2), KMK No. 481 Tahun 1999 (KMK), dan KMK No. 421-426 Tahun 2003 dengan time lag 4 tahun (ASA4) juga menunjukkan nilai yang positif signifikan pada tingkat kepercayaan 99 persen. Sebaliknya, variabel jumlah product line yang ditawarkan (PL), rasio capital expenditure terhadap aset satu tahun sebelumnya (RCAP(-1)), pertumbuhan biaya research and development satu tahun sebelumnya (GRND(-1)), pertumbuhan jumlah agen (GAGN), dan variabel dummy krisis ekonomi tidak berpengaruh terhadap pertumbuhan premi bruto.

Angka koefisien variabel GSDM sebesar 0,3782 menunjukkan bahwa setiap peningkatan 1 persen pada pertumbuhan biaya SDM, dengan asumsi ceteris paribus, akan menyebabkan pertumbuhan premi bruto rata-rata 0,3782 persen. Kemudian, koefisien variabel pertumbuhan GARE sebesar 0,3112 menunjukkan bahwa jika faktor-faktor lainnya tidak mengalami perubahan, maka setiap peningkatan 1 persen pada pertumbuhan biaya agentrelated akan menyebabkan meningkatnya pertumbuhan premi bruto rata-rata 0,3112 persen. Temuan ini sangat menarik karena menunjukkan pentingnya peran SDM bagi perusahaan asuransi jiwa dalam mendukung pertumbuhan premi brutonya.

Tidak signifikannya koefisien variabel GAGN mengimplikasikan bahwa kualitas agen asuransi lebih penting daripada kuantitas agen asuransi dalam mendorong pertumbuhan premi bruto perusahaan asuransi jiwa. Banyaknya agen yang dimiliki perusahaan asuransi jiwa bukan merupakan jaminan kesuksesan dari perusahaan tersebut dalam meningkatkan premi brutonya. Investasi perusahaan asuransi jiwa pada agen, baik dalam bentuk pelatihan yang intensif maupun komisi yang layak, merupakan faktor yang lebih dominan dalam menentukan kesuksesan perusahaan asuransi jiwa dalam meningkatkan premi brutonya. 
Signifikannya koefisien variabel dummy PAKDES2 dan UU2 pada tingkat kepercayaan 99 persen menunjukkan bahwa kebijakan pemerintah berupa Paket Desember Tahun 1988 dan UU No. 2 Tahun 1992 tentang Usaha Perasuransian memberikan dampak positif terhadap pertumbuhan premi bruto industri asuransi jiwa di Indonesia. Namun kedua kebijakan terbukti baru efektif 2 tahun kemudian setelah dikeluarkan oleh pemerintah. Makna lainnya adalah bahwa terdapat dinergi di antara Paket Desember Tahun 1988 dengan UU No. 2 Tahun 1992.

Koefisien variabel dummy ASA4 yang signifikan pada tingkat kepercayaan 99 persen menunjukkan bahwa KMK No. 421426 Tahun 2003 memberikan dampak positif terhadap pertumbuhan premi bruto industri asuransi jiwa di Indonesia. Akan tetapi, dampak tersebut baru dirasakan dalam kurun waktu 4 tahun kemudian setelah KMK-KMK tersebut dikeluarkan oleh pemerinah. Temuan ini memperkuat temuan mengenai pengaruh PAKDES2 dan UU2 yang menunjukkan bahwa peran pemerintah dengan berbagai paket kebijakannya sangat penting dalam mendorong pertumbuhan industri asuransi jiwa di Indonesia.

Fenomena lainnya yang menarik adalah signifikannya koefisien variabel dummy KMK No. 481 Tahun 1999, namun dengan tanda negatif. Inti dari kebijakan ini adalah sebagai antisipasi atas dampak krisis ekonomi terhadap industri asuransi jiwa di Indonesia. Negatifnya tanda koefisien menunjukkan bahwa pada saat krisis ekonomi tahun 1997/1998 dan beberapa tahun setelahnya sempat terjadi penurunan laju pertumbuhan premi bruto asuransi jiwa. Peran dari kebijakan tersebut adalah untuk meredam penurunan laju pertumbuhan premi bruto, sehingga meskipun laju pertumbuhannya menurun, tetapi industri asuransi jiwa tetap dapat tumbuh positif.

Koefisien variabel independen yang terakhir, yaitu koefisien variabel dummy DJV, diketahui signifikan pada tingkat kepercayaan 99 persen dan bertanda positif. Fakta ini menunjukkan bahwa pertumbuhan premi bruto perusahaan asuransi joint venture relatif lebih tinggi jika dibandingkan dengan perusahaan asuransi nasional di Indonesia. Temuan ini sesuai kondisi actual, yaitu bahwa mayoritas perusahaan asuransi jiwa joint venture memiliki model yang lebih besar daripada perusahaan nasional. Dengan modal yang lebih besar, perusahaanperusahaan asuransi jiwa joint venture mampu untuk membuka kantor cabang yang lebih banyak dan mempekerjakan SDM yang kualitasnya lebih handal. Selain itu, dukungan teknologi informasi dan produkproduk asuransi jiwa yang inovatif dari luar negeri, misalnya unit link, juga mendukung perusahaan-perusahaan joint venture untuk lebih maju.

\section{Model Regresi Panel Dinamis Pertumbuhan Jumlah Polis Uji Chow Pertumbuhan Jumlah Polis}

Uji Chow dilakukan untuk membandingkan model regresi data panel pertumbuhan jumlah polis (GJP) dengan menggunakan model PLS dan FEM. Hasil uji Chow menunjukkan p-value untuk Cross Section F dan Cross Section Chi Square berturut-turut sebesar 0,1366 dan 0,0871. Berarti keduanya lebih besar dari batas kritis 0,05, sehingga $H_{0}$ bahwa model PLS lebih unggul daripada FEM secara statistik tidak dapat ditolak pada tingkat keyakinan 95 persen. Dengan demikian, model PLS lebih direkomendasikan untuk mengestimasi faktor-faktor yang mempengaruhi GJP.

\section{Uji Hausman Pertumbuhan Jumlah Polis}

Uji selanjutnya adalah uji Hausman untuk membandingkan model regresi data panel GJP di antara FEM dan REM. Hasil uji Hausman menunjukkan bahwa nilai $p$-value untuk Cross Section Random sebesar 0,0377 yang lebih kecil dari 0,05. Berarti $H_{0}$ bahwa REM lebih unggul daripada FEM secara statistik dapat ditolak pada tingkat keyakinan 95 persen. Berdasarkan hasil ini, maka FEM lebih direkomendasikan untuk mengestimasi faktor-faktor yang mempengaruhi GJP. 
Model Awal Pertumbuhan Jumlah Polis

Hasil uji Hausman menunjukkan bahwa FEM lebih unggul jika dibandingkan dengan REM, sedangkan hasil uji Chow menunjukkan bahwa model PLSlebih unggul daripada FEM. Dengan demikian, model PLS merupakan model yang paling optimal untuk digunakan dalam mencari pengaruh berbagai faktor terhadap pertumbuhan jumlah polis.

\section{Uji Serial Correlation Dan Heteroscedasticity Model Pertumbuhan Jumlah Polis}

Setelah diperoleh model awal Pertumbuhan Jumlah Polis (GJP) dengan model PLS, maka perlu dilakukan pengujian asumsi klasik pada model tersebut dan dilakukan penyesuaian model apabila ditemukan pelanggaran. Uji asumsi klasik yang dilakukan meliputi korelasi serial dan heteroskedastisitas.

Uji heteroskedastisitas dilakukan dengan menggunakan pendekatan LM. P-value untuk statistik Chi-Square uji LM diketahui sebesar 0,0000. Angka ini adalah lebih kecil dari 0,01 , sehingga $H_{0}$ bahwa model bersifat homoskedastik ditolak pada tingkat kepercayaan 99 persen. Hal ini menyebabkan model bersifat lancing, sehingga belum layak untuk dianalisis lebih lanjut. Dengan mengikuti Sanjoyo (2007), pemecahan terhadap permasalahan keberadaan heteroskedastisitas ini adalah dengan melakukan estimasi ulang terhadap model. Estimasi ulang ditempuh dengan menggunakan cross-section weight.

\section{Interpretasi Parameter Model Akhir Regresi Panel Pertumbuhan Jumlah Polis}

Dengan melihat $p$-value diketahui bahwa terdapat 4 variabel, yaitu pertumbuhan jumlah polis 4 tahun sebelumnya (GJP?(-4)), Paket Desember 1988 dengan lag time 2 tahun (PAKDES2), UU No. 2 Tahun 1992 tentang Usaha Perasuransian dengan lag time 2 tahun (UU2), dan KMK No. 481 Tahun 1999 dengan lag time 3 tahun (KMK3), yang berpengaruh signifikan dan positif terhadap pertumbuhan jumlah polis pada tingkat kepercayaan 99 persen. P-value dari koefisien ke-4 variabel tersebut lebih kecil dari 0,01.

Empat variabel lainnya, yaitu pertumbuhan biaya research and development 3 tahun sebelumnya (GRND $(-3))$, pertumbuhan biaya agent-related (GARE?), pertumbuhan jumlah agen (GAGN?), dan KMK No. 421-426 Tahun 2003 dengan lag time 1 tahun (ASA1) berpengaruh signifikan dan positif terhadap pertumbuhan jumlah polis pada tingkat kepercayaan 95 persen. Kesimpulan ini didasarkan pada p-value dari ke-4 variabel yang lebih kecil dari 0,05.

Variabel independen lainnya yang berpengaruh positif dan signifikan terhadap pertumbuhan polis asuransi adalah pertumbuhan biaya SDM (GSDM) dan dummy variabel perusahaan joint venture (DJV). Namun, secara statistik, kedua variabel ini hanya berpengaruh pada tingkat kepercayaan 90 persen. P-value kedua variabel diketahui lebih kecil dari 0,10.

Angka koefisien variabel pertumbuhan biaya SDM (GSDM) sebesar 0,0702 menunjukkan bahwa setiap peningkatan 1 persen pada pertumbuhan biaya SDM dari perusahaan asuransi jiwa akan menyebabkan pertumbuhan jumlah polis meningkat ratarata 0,0702 persen. Kesimpulan ini berlaku dengan asumsi faktor-faktor lainnya tidak berubah. Selanjutnya, koefisien variabel pertumbuhan biaya research and development 3 tahun sebelumnya (GRND(-3)) sebesar 0,0426 berarti bahwa setiap peningkatan 1 persen pada pertumbuhan biaya research and development pada 3 tahun yang lalu, dengan asumsi ceteris paribus, akan menyebabkan peningkatan pertumbuhan jumlah polis pada tahun ini rata-rata 0,0426 persen.

Hasil estimasi angka koefisien variabel pertumbuhan biaya agent-related (GARE) sebesar 0,0160 menunjukkan bahwa apabila faktor-faktor lainnya tidak mengalami perubahan, maka setiap peningkatan 1 persen pada pertumbuhan biaya agentrelated akan menyebabkan meningkatnya pertumbuhan jumlah polis rata-rata 0,0160 
persen. Kemudian, angka koefisien variabel pertumbuhan jumlah agen (GAGN) sebesar 0,0860 menunjukkan bahwa setiap peningkatan 1 persen pada pertumbuhan jumlah agen akan menyebabkan meningkatnya pertumbuhan jumlah polis rata-rata 0,0860 persen, dengan asumsi ceteris paribus. Hasil estimasi lainnya, yaitu angka koefisien variabel pertumbuhan jumlah polis 4 tahun sebelumnya (GJP(-4)) sebesar 0,2755 menunjukkan bahwa, jika faktor-faktor lainnya diasumsikan tidak berubah, maka setiap peningkatan 1 persen pertumbuhan dari jumlah polis 4 tahun sebelumnya akan menyebabkan peningkatan pertumbuhan jumlah polis saat ini rata-rata 0,2755 persen.

Konsisten dengan temuan pada model pertumbuhan premi bruto, sensitivitas per-tumbuhan jumlah polis terhadap pertumbuhan biaya SDM (GSDM) lebih tinggi daripada variabel-variabel independen yang lain. Sebaliknya, berbeda dengan model pertumbuhan premi bruto, pada model pertumbuhan jumlah polis ditemukan bahwa variabel pertumbuhan jumlah agen berpengaruh secara signifikan dan positif pada tingkat kepercayaan 95 persen. Kedua temuan ini memperkuat kesimpulan bahwa SDM dan agen asuransi merupakan faktor yang sangat vital dalam menunjang pertumbuhan jumlah polis perusahaan asuransi jiwa. Signifikannya pengaruh variabel pertumbuhan biaya agent-related dan pertumbuhan jumlah agen secara bersamasama terhadap pertumbuhan jumlah polis menunjukkan bahwa kuantitas dan kualitas agen asuransi jiwa sama-sama penting untuk meningkatkan jumlah polis asuransi jiwa yang terjual.

Pengaruh koefisien variabel dummy PAKDES2 dan UU2 yang signifikan pada tingkat kepercayaan 99 persen menunjukkan bahwa kebijakan pemerintah berupa Paket Desember 1988 dan UU No. 2 Tahun 1992 tentang Usaha Perasuransian baru memberikan dampak positif terhadap pertumbuhan jumlah polis industri asuransi jiwa di Indonesia 2 tahun setelah kebijakankebijakan tersebut dikeluarkan. Hal ini memperkuat dugaan bahwa di antara Paket Desember 1988 dan UU No. 2 Tahun 1992 saling bersinergi.

Signifikannya koefisien variabel dummy ASA1 pada tingkat kepercayaan 95 persen menunjukkan bahwa kebijakan pemerintah berupa KMK No. 421-426 Tahun 2003 memberikan dampak positif terhadap pertumbuhan jumlah polis industri asuransi jiwa di Indonesia segera (1 tahun) setelah KMK-KMK tersebut dikeluarkan oleh pemerinah. Temuan yang terkait dengan kebijakan pemerintah menunjukkan bahwa peran pemerintah dengan berbagai paket kebijakannya sangat penting dalam mendorong pertumbuhan industri asuransi jiwa di Indonesia.

Berbeda dengan temuan sebelumnya pada model pertumbuhan premi bruto, koefisien variabel dummy KMK No. 481 Tahun 1999 dengan lag time 3 tahun (KMK3) memiliki tanda positif dan signifikan pada tingkat kepercayaan 99 persen. Hal ini menunjukkan keberhasilan pemerintah dalam mengatasi dampak krisis ekonomi terhadap pertumbuhan jumlah polis, sehingga berkontribusi bagi ketahanan industri asuransi jiwa di Indonesia dari terpaan krisis.

Sebagai variabel yang terakhir, signifikannya koefisien variabel dummy perusahaan joint venture (DJV) menunjukkan bahwa pertumbuhan premi bruto perusahaan asuransi joint venture relatif lebih tinggi daripada perusahaan asuransi nasional di Indonesia. Dalam faktanya perusahaan-perusahaan asuransi jiwa yang berstatus joint venture memiliki model yang lebih kuat. Sebagai konsekuensinya, kantorkantor cabang yang dimiliki lebih banyak, sehingga jaringan pemasaran menjadi lebih luas. Di samping itu, perusahaan asuransi jiwa joint venture mampu mempekerjakan SDM yang lebih mumpuni. Sarana dan prasarana yang tersedia juga lebih lengkap, termasuk dukungan teknologi canggih yang dihasilkan dari inovasi tanpa henti. 
Model Regresi Panel Dinamis
Pertumbuhan Uang Pertanggungan
Uji Chow Pertumbuhan Jumlah Uang
Pertanggungan
Uji Chow dilakukan untuk membandingkan model regresi panel variabel pertumbuhan jumlah uang pertanggungan (GUP) dengan menggunakan model PLS dan FEM.. P-value untuk Cross Section F dan Cross Section Chi Square berturut-turut adalah 0,2744 dan 0,2094. Kedua angka ini lebih besar dari 0,05 . Berarti $H_{0}$ bahwa model PLS lebih unggul daripada FEM tidak dapat ditolak pada tingkat keyakinan 95 persen. Dengan demikian, model PLS lebih direkomendasikan untuk mengestimasi faktor-faktor yang mempengaruhi GUP.

\section{Uji Hausman Pertumbuhan Jumlah Uang Pertanggungan}

Selanjutnya dilakukan uji Hausman untuk memilih model regresi panel GUP yang terbaik di antara model FEM dan REM. Hasil uji Hausman menunjukkan nilai p-value untuk Cross Section Random sebesar 0,0272 yang lebih kecil dari 0,05. Maknanya adalah $H_{0}$ bahwa REM lebih unggul daripada FEM dapat ditolak pada tingkat keyakinan 95 persen. Kesimpulannya adalah bahwa FEM lebih direkomendasikan untuk melacak berbagai faktor yang berpengaruh terhadap GUP.

\section{Model Awal Regresi Panel Pertumbuhan Jumlah Uang Pertanggungan}

Jika dilakukan perbandingan hasil uji di antara kedua uji, maka hasil uji Hausman menunjukkan bahwa FEM lebih unggul daripada REM, sedangkan hasil uji Chow menunjukkan bahwa model PLS lebih unggul daripada FEM. Dengan demikian, model PLS adalah model yang paling optimal untuk memodelkan faktor-faktor yang mempengaruhi pertumbuhan jumlah uang pertanggungan.

Model PLS pertumbuhan jumlah uang pertanggungan diestimasi setelah terlebih dahulu dimasukkan variabel-variabel yang terdiri dari dummy Paket Desember 1988 (PAKDES), UU No. 2 Tahun 1992 tentang Usaha Perasuransian (UU), KMK No. 481 Tahun 1999 (KMK), rangkaian KMK No. 421426 tahun 2003 (ASA), serta kondisi krisis (DKRISIS), dan perusahaan asuransi jiwa joint venture (DJV).

\section{Uji Serial Correlation Dan Heteroscedasticity Model Pertumbuhan Jumlah Uang Pertanggungan}

Setelah diperoleh model awal Pertumbuhan Jumlah Uang Pertanggungan (GUP) dengan model PLS, kemudian dilakukan pengujian asumsi klasik pada model tersebut, yaitu korelasi serial dan heteroskedastisitas. Jika ditemukan pelanggaran terhadap asumsi klasik, maka perlu dilakukan penyesuaian terhadap model.

Statistik Durbin Watson untuk persamaan tersebut adalah 2,28. Angka ini relatif mendekati 2, sehingga dapat disimpulkan bahwa model yang telah diestimasi tidak mengandung serial correlation.

Ditemukan bahwa p-value untuk statistik Chi-Square sebesar 0,0000. Angka probabilitas ini lebih kecil dari 0,01. Berarti $H_{0}$ bahwa model bersifat homoskedastik dapat ditolak pada tingkat kepercayaan 99 persen. Dengan kata lain, model yang diestimasi melanggar asumsi klasik, yaitu memiliki heteroskedastisitas, sehingga belum layak dijadikan sebagai alat estimasi. Untuk mengatasi persoalan ini, Sanjoyo (2007) menyarankan untuk melakukan estimasi ulang terhadap model tersebut dengan menggunakan cross-section weight.

\section{Interpretasi Parameter Model Akhir Regresi Panel Pertumbuhan Jumlah Uang Pertanggungan}

Ditemukan tujuh variabel independen yang mempengaruhi pertumbuhan jumlah uang pertanggungan perusahaan asuransi jiwa di Indonesia. Ketujuh variabel berpengaruh positif, namun dengan tingkat signifikansi yang berbeda-beda, sebagaimana 
ditunjukkan oleh angka probabilitas atau p-value-nya. Pertumbuhan biaya agentrelated (GARE?), pertumbuhan jumlah uang pertanggungan 1 tahun sebelumnya (GUP?(1)), Paket Desember 1988 dengan lag time 3 tahun (PAKDES3), UU No. 2 Tahun 1992 dengan lag time 5 tahun (UU5), KMK No. 481 Tahun 1999 dengan lag time 2 tahun (KMK2), dan KMK No. 421-426 Tahun 2003 dengan lag time 2 tahun (ASA2) diketahui signifikan pada tingkat keyakinan 99 persen. Sedangkan variabel pertumbuhan biaya research and development satu tahun sebelumnya (GRND?(-1)) signifikan pada tingkat kepercayaan 95 persen.

Angka koefisien variabel pertumbuhan biaya research and development 1 tahun sebelumnya (GRND(-1)) diketahui sebesar 0,0516 yang berarti bahwa setiap peningkatan satu persen pada pertumbuhan biaya research and development pada satu tahun yang lalu, dengan asumsi ceteris paribus, akan menyebabkan peningkatan pertumbuhan jumlah uang pertanggungan pada tahun ini rata-rata sebesar 0,0515 persen. Selanjutnya, angka koefisien variabel pertumbuhan biaya agent-related (GARE) sebesar 0,0989 menunjukkan bahwa setiap peningkatan satu persen pada pertumbuhan biaya agent-related akan menyebabkan meningkatnya pertumbuhan jumlah uang pertanggungan rata-rata 0,0989 persen. Kesimpulan ini berlaku apabila faktorfaktor lainnya diasumsikan tidak mengalami perubahan. Adapun angka koefisien variabel pertumbuhan jumlah uang pertanggungan satu tahun sebelumnya (GUP(-1)) sebesar 0,3922 menunjukkan bahwa jika faktorfaktor lainnya tidak berubah, maka setiap peningkatan satu persen pertumbuhan jumlah uang pertanggungan 1 tahun sebelumnya akan menyebabkan peningkatan pertumbuhan jumlah uang pertanggungan saat ini rata-rata sebesar 0,3922 persen.

Sensitivitas pertumbuhan jumlah polis terhadap pertumbuhan biaya agent-related (GARE) lebih tinggi daripada terhadap biaya research and development 1 tahun sebelumnya (GRND(-1)). Namun, berbeda dengan temuan pada model pertumbuhan jumlah polis, pada model pertumbuhan jumlah uang pertanggungan ditemukan bahwa variabel pertumbuhan jumlah agen kembali tidak berpengaruh. Temuan-temuan ini mendukung kesimpulan bahwa agen asuransi merupakan faktor yang sangat vital dalam menunjang pertumbuhan jumlah polis perusahaan asuransi jiwa. Selain faktor agen, riset, dan pengembangan yang dilakukan perusahaan, misalnya dalam mengembangkan produk-produk yang lebih kompleks dan mengerti kebutuhan masyarakat, juga penting sebagai faktor yang menentukan pertumbuhan jumlah uang pertanggungan industri asuransi jiwa di Indonesia.

Signifikannya koefisien variabel dummy PAKDES3 dan UU5 pada tingkat kepercayaan 99 persen menunjukkan bahwa kebijakan pemerintah baru memberikan dampak positif terhadap pertumbuhan jumlah polis industri asuransi jiwa di Indonesia 3 tahun dan 5 tahun setelah kebijakan-kebijakan tersebut dikeluarkan oleh pemerintah. Suatu periode yang cukup lama bagi pelaku bisnis yang pada umumnya menghadapi pasar yang dinamis. Adapun signifikannya koefisien variabel dummy ASA2 tingkat kepercayaan yang sama (99 persen) menunjukkan bahwa kebijakan pemerintah berupa KMK No. 421426 tahun 2003 memberikan dampak positif terhadap pertumbuhan jumlah polis industri asuransi jiwa di Indonesia 2 tahun setelah KMK-KMK tersebut dikeluarkan.

\section{Hasil Pengujian Hipotesis}

Uji hipotesis dilakukan dengan menggunakan metode regresi panel dinamis untuk mengetahui pengaruh variabel independen keragaman produk, sarana dan prasarana penunjang, kepemilikan asing (joint venture), serta kebijakan pemerintah terhadap variabel dependen pertumbuhan premi bruto, jumlah polis, dan uang pertanggungan. Dari variabel keragaman produk, sebagaimana diproksi oleh jumlah product line yang ditawarkan, tidak ada yang signifikan dalam ketiga model persamaan 
regresi panel dinamis (GPB, GJP, dan GUP). Berarti hipotesis bahwa keragaman produk berpengaruh positif terhadap pertumbuhan premi bruto, jumlah polis, dan uang pertanggungan industri asuransi jiwa, tidak dapat dibuktikan. Fakta ini bertentangan dengan hasil wawancara kepada direksi 15 perusahaan asuransi jiwa. Mayoritas direksi menyatakan bahwa keragaman produk merupakan determinan yang penting pada pertumbuhan industri asuransi jiwa di Indonesia. Peneliti menduga bahwa hal ini terkait dengan penggunaan definisi keragaman produk dari regulator yang secara keseluruhan hanya terdiri dari 7 kategori, yaitu term, endowment, whole life, annuity, personal accident, health, dan investmentlinked insurance. Padahal, dalam praktiknya, banyak sekali jenis produk asuransi jiwa, namun datanya tidak tersedia secara lengkap di masing-masing perusahaan asuransi jiwa.

Dari kelima sub variabel sarana dan prasarana penunjang, hanya rasio capital expenditure terhadap aset yang tidak signifikan dalam menjelaskan pertumbuhan premi bruto, jumlah polis, dan uang pertanggungan. Sedangkan pertumbuhan biaya SDM, biaya research and development, biaya agent-related, dan jumlah agen mempunyai pengaruh yang signifikan dan positif. Hal ini mengimplikasikan bahwa dalam industri asuransi jiwa, faktor manusia adalah kunci sukses yang paling penting, terutama yang berkaitan dengan para agen asuransi.

Pertumbuhan biaya agent-related diketahui memiliki tingkat signifikansi yang lebih tinggi dibandingkan pertumbuhan jumlah agen. Maknanya bahwa kesuksesan perusahaan asuransi jiwa di Indonesia lebih ditentukan oleh "kualitas" para agennya, dibandingkan dengan "kuantitas" para agennya. Dengan demikian, hipotesis bahwa sarana dan prasarana berpengaruh positif pada pertumbuhan premi bruto, jumlah polis, dan jumlah uang pertanggungan, dapat dibuktikan dalam penelitian ini.

Selanjutnya pengaruh variabel kepemilikan asing, yang diproksi dari variabel dummy joint venture (DJV), menunjukkan pengaruh yang signifikan dan positif terhadap pertumbuhan premi bruto dan jumlah polis, namun tidak signifikan terhadap pertumbuhan uang pertanggungan. Dapat disimpulkan hipotesis bahwa kepemilikan asing berpengaruh positif terhadap pertumbuhan premi bruto, jumlah polis, dan uang pertanggungan, dapat dibuktikan, meskipun hanya secara parsial.

Variabel kebijakan pemerintah, baik Pakdes 1988, UU No. 2 Tahun 1992, KMK No. 481 Tahun 1999, dan KMK No. 421-426 Tahun 2003 menunjukkan pengaruh yang signifikan dan positif terhadap pertumbuhan premi bruto, jumlah polis, dan uang pertanggungan. Namun, KMK No. 481 Tahun 1999 menunjukkan pengaruh signifikan dan negatif terhadap pertumbuhan premi bruto. Kebijakan-kebijakan tersebutjuga mengalami jeda waktu dari saat ditetapkan hingga saat mulai berdampak pada industri asuransi jiwa di Indonesia. Pengaruh positif dari kebijakan pemerintah mendorong industri asuransi jiwa di Indonesia tetap tumbuh, meskipun terkena krisis ekonomi. Hal ini dapat dibuktikan dari tidak signifikannya variabel dummy krisis pada ketiga persamaan regresi panel dinamis.

\section{SIMPULAN}

Variabel keragaman produk tidak signifikan dalam menjelaskan pertumbuhan premi bruto, jumlah polis, dan uang pertanggungan. Sarana dan prasarana penunjang yang berpengaruh signifikan dan positif dalam menjelaskan pertumbuhan premi bruto, jumlah polis, dan uang pertanggungan adalah pertumbuhan biaya research and development, pertumbuhan biaya SDM, dan pertumbuhan biaya agent-related. Pertumbuhan biaya research and development memiliki lag time antara 1-3 tahun.

Keragaman produk tidak berpengaruh terhadap pertumbuhan premi bruto, jumlah polis, dan uang pertanggungan asuransi jiwa. Variabel yang terpenting adalah ekstensifikasi dari masing-masing jenis produk dan bukan keragaman produk sebagaimana ditunjukkan 
oleh jenis produk asuransi jiwa yang dikelompokkan oleh pemerintah.Kebijakan pemerintah, baik Pakdes 1988, UU No. 2 Tahun 1992, dan KMK No. 421-426 Tahun 2003 berpengaruh signifikan dan positif terhadap pertumbuhan premi bruto, jumlah polis, dan uang pertanggungan perusahaan asuransi. Lag time kebijakan Pakdes 1988 antara 2-3 tahun, UU No. 2 Tahun 1992 antara 2-5 tahun, dan KMK No. 421-426 Tahun 2003 antara 1-4 tahun.

Untuk KMK No. 481 Tahun 1999, yang ditujukan sebagai antisipasi krisis, menunjukkan pengaruh yang signifikan dan positif terhadap pertumbuhan jumlah polis dan uang pertanggungan dengan lag time antara 2-3 tahun pasca krisis ekonomi. Temuan ini mengimplikasikan keberhasilan kebijakan pemerintah untuk meningkatkan ketahanan industri asuransi jiwa di Indonesia dari ancaman krisis. Meskipun berkontribusi signifikan dan negatif terhadap pertumbuhan jumlah premi bruto, namun hal ini masih dapat dimaklumi mengingat krisis ekonomi menyebabkan terjadinya penurunan laju pertumbuhan premi bruto.

\section{DAFTAR PUSTAKA}

Anonim, 1945. Undang-Undang Dasar Republik Indonesia. Pemerintah Republik Indonesia.

Anonim, 1992. Undang-Undang Republik Indonesia Nomor 2 Tahun 1992 tentang Usaha Perasuransian. Pemerintah Republik Indonesia.

Anonim, 2004. Undang-Undang Republik Indonesia Nomor 10 Tahun 2004. Pemerintah Republik Indonesia.

Anonim, 2006. Membuka Potensi Sumber Daya Keuangan Dalam Negeri Indonesia: Peran Lembaga Keuangan Non-Bank. Jakarta: Bank Dunia.

Anonim, 2007. Informasi Asuransi On-Line. http:/ / informasi-asuransi.blogspot. com.

Anonim, 2009. Indonesian Insurance in 2008. Jakarta: Biro Perasuransian, Bapepam-LK.
Anonim, 2010. Kajian Stabilitas Keuangan. No. 14 Edisi Maret 2010. Jakarta: Bank Indonesia.

Adanza, Estela G. 1995. Research Methods: Principles and Applications. Manila: Rex Book Store, Inc.

Babbel, David F., 1985. The Price Elasticity of Demand for Whole Life Insurance. The Journal of Finance, Vol. XL, No.1.

Beck, Thorsten dan Ian Webb, 2002. Determinants of Life Insurance Consumption accross Countries. Worldbank and International Insurance Foundation.

Berutu, Eddy KA, 2007. Indonesia Bakal Menjadi Macan Asia? www.kompascetak.com.

Brooks, Chris, 2008. Introductory Econometrics for Finance. $2^{\text {nd }}$ edition. Cambridge: Cambridge University Press.

Browne, Mark J. dan Kihong Kim, 1993. An International Analysis of Life Insurance Demand. The Journal of Risk and Insurance, Vol. 60, No.4.

Cargill, T. F. dan T. E. Troxel, 1979. Modelling Life Insurance Savings: A Methodological Issues. The Journal of Risk and Insurance, Vol. 46, No.2.

Campbell, David dan Tom Craig, 2005. Organisations and the Business Environment. 2nd edition. Oxford: Elsevier Butterworth-Heinemann.

Carmichael, Jeffrey dan Michael Pomerleano, 2002. The Development and Regulation of Non-Bank Financial Institutions. Washington D.C.: The International Bank for Reconstruction and Development/The World Bank.

Cooper, David.R., 1996. Business Research Methods, $4^{\text {th }}$ Edition. New York: Prentice Hall, Inc..

Cronbach, L. J., 1951. Coefficient Alpha and The Internal Structure of Tests. Psychometrika, Vol. 16 (3): 297-334. 
Darmodiharjo, D. dan Shidarta, 2006. PokokPokok Filasafat Hukum: Apa dan Bagaimana Filsafat Hukum Indonesia. Cetakan Keenam. Jakarta: Gramedia Pustaka Utama.

Djaelani, Firdaus (2009). "Pengaruh Pergerakan Variabel Makrokonomi pada Permintaan Industri Asuransi Jiwa di Indonesia". Artikel yang belum diterbitkan.

Eduard, 2004. Model Permintaan Asuransi Jiwa dengan Metode Logit Biner. Program S2-Manajemen dan Teknik Industri. Bandung: Institut Teknologi Bandung.

Enders, Walter, 2003. Applied Econometrics Techniques, $2^{\text {nd }}$ Edition. New York: Wiley and Sons, Inc.

Freixas, Xavier dan Jean-Charles Rochet, 2008. Microeconomics of Banking. 2nd edition. London: The MIT Press.

Fuad, Noor, Kasir Iskandar, Ketut Sendra, Faustinus Wirasadi. 2010. DasarDasar Asuransi Jiwa dan Asuransi Kesehatan. Edisi Perdana. Jakarta: Bidang Penelitian dan Pengembangan Asosiasi Ahli Manajemen Asuransi Indonesia.

Greene, William H., 2002. Econometric Analysis, $5^{\text {th }}$ Edition, New Jersey: Prentice Hall.

Gujarati, Damodar N., 2004. Basic Econometrics, $4^{\text {th }}$ edition. New York: McGraw-Hill Companies.

Hair, Joseph F., Jr., RE. Anderson, RL. Tatham, dan WC. Black, 1998. Multivariate Data Analysis (International Edition), $5^{\text {th }}$ edition. New Jersey: Prentice Hall.

Hsiao, Cheng, 2003. Analysis of Panel Data. New York: Cambridge University Press.

Kotler, Philip dan Kevin Lane Keller, 2006. Marketing Management. $12^{\text {th }}$ edition. New Jersey: Pearson Education, Inc.

Kutner, M.H., C.J. Nachtseim dan J. Neter, 2004. Applied Linear Regression
Models. $4^{\text {th }}$ edition. Singapore: The McGraw-Hill Companies, Inc.

Lenten, Liam J.A. dan David N. Rulli, 2005. A Time-Series Analysis of The Demand for Life Insurance Companies in Australia: An Unobserved Components Approach. Department of Economics and Finance, Victoria: Latrobe University.

Lim, Chee Chee dan Steven Haberman, 2004. Modelling Life Insurance Demand from a Macroeconomic Perspective: The Malaysian Case. Faculty of Actuarial Science and Statistics, London: CASS Business School.

Mankiw, Gregory. N, 2005. The Principles of Economics. New York: Pearson Education.

Mankiw, Gregory. N, 2006. The Principles of Microeconomics. 4th edition. New York: Pearson Education.

Mishkin, Frederick S., 2004. The Economics of Money, Banking, and Financial Markets, $7^{\text {th }}$ Edition. New York: Pearson Education.

Nachrowi, Nachrowi D. dan Hardius Usman, 2005. Pengantar Ekonometrika dengan Aplikasi Komputer. Jakarta: Lembaga Penerbit FEUI.

Outreville, J. Francois, 1996. Life Insurance Markets in Developing Countries. The Journal of Risk and Insurance, Vol. 63, No. 2.

Porter, Ian, 2002. How Can Non-Bank Financial Institutions (NBFIs) Play a Greater Role in a Bank-Based Economy?. Remarks by The World Bank Country Director of Southeast Asia and Mongolia.

Pyndickdan Rubienfield. 2003. Microeconomics. New York: Prentice Hall.

Robbins, Stephen P. dan Mary Coulter, 2005. Management, $8^{\text {th }}$ Edition. New York: Prentice Hall Inc.

Rochma, Malia, 2007. Prospek Industri Asuransi Jiwa di Indonesia. Economic Review No. 210 edisi Desember 2007. 
Rose, Peter S., 2000. Money and Capital Markets: Financial Institutions Instruments in The Global Marketplace, $7^{\text {th }}$ Edition. Texas A\&M University.

Rubayah, Y. dan Zaidi, 2000. Prospek Industri Insurans Hayat Abad Ke-21. Utara Management Review, Vol. 36, No. 6.

Sanjoyo, 2007. Analisis Data Panel. Program Pascasarjana Jenjang Doktoral, Fakultas Ekonomi, Universitas Indonesia.

Sarwono, Jonathan, 2007. Analisis Jalur untuk Riset Bisnis dengan SPSS. Jakarta: ANDI.

Sadgrove, Kit, 2003. A Complete Guide to Business Risk Management. Singapore: Singapore Publishing.

Sekaran, Uma, 2002. Research Methods for Business, $5^{\text {th }}$ Edition. New York: John Wiley and Son, Inc.

Simandjuntak, Herris B., 2003. Bisnis Asuransi Jiwa Masih Cerah, Banyak Pula Tantangannya. www.kompas-cetak.com.

Sugiyono, 2004. Metode Penelitian Bisnis. Cetakan Keenam. Bandung: Alfabeta.

Trochim, William M.K., 2006. Research Methods knowledge Base. Online E-book at http://onlinebooks. library.upenn.edu/webbin/book/ lookupname?key=Trochim $\% 2 \mathrm{C} \% 20$ William\%20M.
Tracy, Brian, 2007. Apply the 80/20 Rule to Everything. San Fransisco: BerrettKoehler Publishers, Inc.

Truett, Dale B. Dan Lila J.Truet, 1990. The Demand for Life Insurance in Mexico and The United States: A Comparative Study. The Journal of Risk and Insurance, Vol. 57, No. 2.

Vittas, Dimitri, 1998. The Role of Non-Bank Financial Intermediaries (with particular reference to Egypt). World Bank Policy Research Working Paper 1892.

Walpole, Ronald E., 1993. Pengantar Statistika. Jakarta: PT Gramedia Pustaka Utama.

Warjiyo, Perry, 2007. Market and Monetary Environment-What and Why? Pascasarjana Fakultas Ekonomi. Jakarta: Universitas Indonesia.

Wright, Kenneth M., 1992. The Life Insurance Industry in the United States: An Analysis of Economic and Regulatory Issues. Working Papers Financial Policy and Systems: 1-54.

Yaffee, Robert, 2005. A Primer for Panel Data Analysis. Online Connect Information Technology at New York University (NYU), Fall 2003 edition. http:// www.nyu.edu/its/pubs/connect/ fall03/yaffee_primer.html.

Zikmund, W.G., 2000. Business Research Methods. $6^{\text {th }}$ edition. Orlando: Hartcourt College Publishers. 